\title{
How Stable is Dualisation? The Case of Labour Market and Antipoverty Policies in Italy*
}

\author{
Andrea Ciarini**, Roberto Rizza***
}

\begin{abstract}
This article analyses the old and new dualisation processes that have emerged in Italy in the last twenty years. By focusing on the dualising outcomes of labour market and antipoverty policies, it addresses the trajectories followed by dualisation and their effects on the divides between insiders and outsiders. Within this framework it is argued that dualisation is not a stable equilibrium, but rather the result of the interconnections between institutional arrangements and the variable decisions of social and political actors.

Keywords: dualisation, labour market, poverty
\end{abstract}

\section{Introduction}

There are various ways of conceptualising the processes involved in the dualisation of contemporary societies. In general, dualisation refers to the increasing inequalities, in the labour market and in welfare systems, between "insiders" and "outsiders" (Emmenegger et al., 2012; Rueda, 2014).

This concept is often used together with, or as a synonym of segmentation. In reality, these are different phenomena. Studies of labour market segmentation (Berger and Piore, 1980; Piore, 1980; Kalleberg, 2003), which preceded those of dualisation, focused on the clear distinction between two separate segments of the labour force in advanced economies. On the one hand, there is the primary labour market comprising the most

${ }^{*}$ Articolo proposto: 21/10/2020. Articolo accettato: 10/01/2021.

** Sapienza University of Rome. E-mail: andrea.ciarini@uniroma1.it.

*** University of Bologna. E-mail: roberto.rizza@unibo.it.

Sociologia del lavoro, n. 159/2021. ISSN 0392-5048. ISSNe 1972-554X.

DOI: $10.3280 /$ SL2021-159005 
highly-qualified, unionised, better paid jobs that are afforded greater protection in terms of contractual conditions and welfare rights. On the other hand, there is the secondary market, characterised by low wages, poorer working conditions and job instability, and reserved for younger people, women and immigrants. This strand of literature sees dualisation as an expression of the selective dynamics of labour demand.

Clearly the two concepts of "segmentation" and "dualisation" are closely related, and as such are often considered interchangeable. However, there are a number of substantial differences between the two. While segmentation refers to the macro-structural conditions under which the labour force is selected and absorbed into the labour market by firms, dualisation refers to a political-institutional dimension of the divergences present in the labour market, the welfare state and political/trade-union representation (Palier and Thelen, 2010; Emmenegger et al., 2012; Thelen, 2014). In this sense, dualisation is the outcome of political decisions and of power relations between various groups of actors possessing different powers and voices vis-à-vis governmental coalitions and representative organisations more interested in safeguarding the interests of their own core voters or members (the insiders) than those of weaker, less unionised categories.

With regard to the paths taken by dualisation in both time and space, authors in the contemporary political economy literature (see, in particular, Emmenegger et al., 2012) argue that such dualisms are not simply the result of structural changes (service economy, de-industrialisation, increasing inequality), but also of political-institutional factors, that is, decisions regarding the regulation or deregulation of the labour market, which conceal a series of vested interests and power relations. Seen from this perspective, in the face of pressures deriving from globalisation and the post-industrial transition, some scholars maintain that social-democratic parties and trade unions alike tend to favour the protection of insiders, thus burdening the outsiders with the costs of structural readjustments (Rueda, 2007). This path-dependent character of dualisation (Emmenegger et al., 2012; Hassel, 2014; Palier and Thelen, 2010) tends to reflect a steady equilibrium for a series of reasons relating to the political-electoral force of the insiders, to the detriment of the outsiders (Emmenegger et al., 2012), who are less well represented and protected in political-trade union terms. Nevertheless, as Pontusson shows (2009), cross-national comparisons continue to show that inequality, by almost any measure, is lowest in countries where SocialDemocractic parties are the strongest. More generally, and at the level of institutional change, Thelen (2014) uses the concept of "drift" to describe a process whereby institutional arrangements developed in the past in the industrial sector are not extended beyond the manufacturing core. 
Nevertheless, more fluid situations may also exist. As Eichhorst and Marx (2019) point out, during periods of high unemployment insiders can sustain dualisation by offloading the costs of flexibility on outsiders. In contrast during times of economic growth a greater degree of regulation may be preferable, also in relation to the outsiders, if pressure to lower salaries and levels of welfare protection is to be eased, given the increasing competition between protected and unprotected categories of workers. In fact, political economy scholars disagree on the nature of dualism: there are those who emphasise its path-dependent character, whereas others favour more dynamic interpretations of institutional change, with specific attention to the interconnections between institutional arrangements (of the labour market and of the welfare system) and the time- and spatially-variable decisions of social and political actors (Thelen, 2014).

In Mediterranean countries, dualisation traditionally runs along the lines of deep divides in terms of age and gender, as well as substantial regional differences within the same country (Esping-Andersen and Regini, 2000; Barbieri and Scherer, 2005). These divides comprise: a generally lower level of female employment compared to men, this level being extremely low in certain southern regions; the preponderantly (involuntary) part-time nature of female employment; the high rate of youth unemployment, which in certain regions is extreme; the concentration of "atypical" employment among young people, and a limited degree of transition from temporary to permanent employment; a demand for labour that is oriented towards the need for medium-low skilled workers, together with the increasingly high level of education attained by young people in general (Saraceno, Benassi and Morlicchio, 2020).

The present article focus on the old and new dualisms that have emerged in Italy in recent years, and in particular on the dualising outcomes of social and labour market policies on the one hand, and on the coalitions of actors who have been behind the policy decisions taken, on the other. The questions we wish to address are as follows: how have the various aspects of dualisation changed in Italy over the past twenty years? How and to what extent, have institutional contexts impacted the direction taken by dualisation, and with what outcomes compared to the traditional divergences between insiders and outsiders? Finally, what role has been played by collective actors in response to structural pressures, including those induced by the recent pandemic?

While acknowledging the existence of a series of exogenous shocks, the following analysis is based on a study of endogenous change. In other words, the changes in the policy areas examined here, and the institutional arrangements put in place over the course of time, will not be seen as mere 
reactions to external shocks; on the contrary, we shall view the change as a response to turning points shaped by the interaction of collective actors and governments (Greif and Laitin, 2004; Hall and Thelen, 2008).

The areas we are examining are labour market policies and assistance policies designed to counter the risk of poverty. Italy has traditionally never had a truly national policy for fighting poverty, whereas there have been successive reforms in the regulation of labour market, with the implementation of both passive and active measures (see section 2 ). It was only very recently (between 2017 and 2018) that Italy managed to reorganise its efforts to counter poverty, with the introduction of two reforms that have not only radically changed the institutional framework, but have also modified the profile of those targeted by such policy; this has been achieved by strictly correlating the fight against poverty with active measures to help people back into work. All of this renders the continuum between labour policies and anti-poverty measures extremely interesting from the viewpoint of the reconfiguration of the forms of dualisation, particularly in view of the consequences of the current pandemic and the consequent deep economic downturn.

\section{Labour market policy in Italy: two forms of dualisation}

In Italy, labour market regulation feature two main aspects of dualisation, meaning the diversified protection afforded to different groups of workers The first of these dates from the early 1970s, and concerns employment protection legislation: it consists in the difference established, in regard to workers with permanent jobs, between those who work for companies with fewer than 15 employees, and those who work for companies employing 15 or more people. This is an important aspect of dualisation given that a great many people work for small firms or businesses in Italy. The second aspect of dualisation emerged during the 1990s, when the deregulation of the labour market liberalised temporary jobs, with the consequence of a greater number of people being hired on temporary contracts when entering the labour market. The liberalisation of temporary employment resulted therefore in more young workers starting work on temporary contracts, particularly during the 2000s (Barbieri and Scherer, 2005).

This double dualisation has significant consequences: on the one hand, it means less legal protection for those fired by companies with fewer than 15 employees; on the other hand, it has resulted in reduced protection during periods of unemployment among workers on temporary contracts, as a result of the eligibility criteria for unemployment benefits. Berton et al. 
(2012) have estimated that in the case of Italy, prior to $2012,40 \%$ of temporary workers and $50 \%$ of temporary agency workers were without any income support when made unemployed, and that these percentages are even higher in the case of part-time temporary workers. Furthermore, given that temporary employment tends to be more prevalent among young people, the dualisation encouraged by labour market policy has resulted in substantial differences among diverse age categories (see Fig. 1).

Fig 1 - Temporary employment by age in Italy

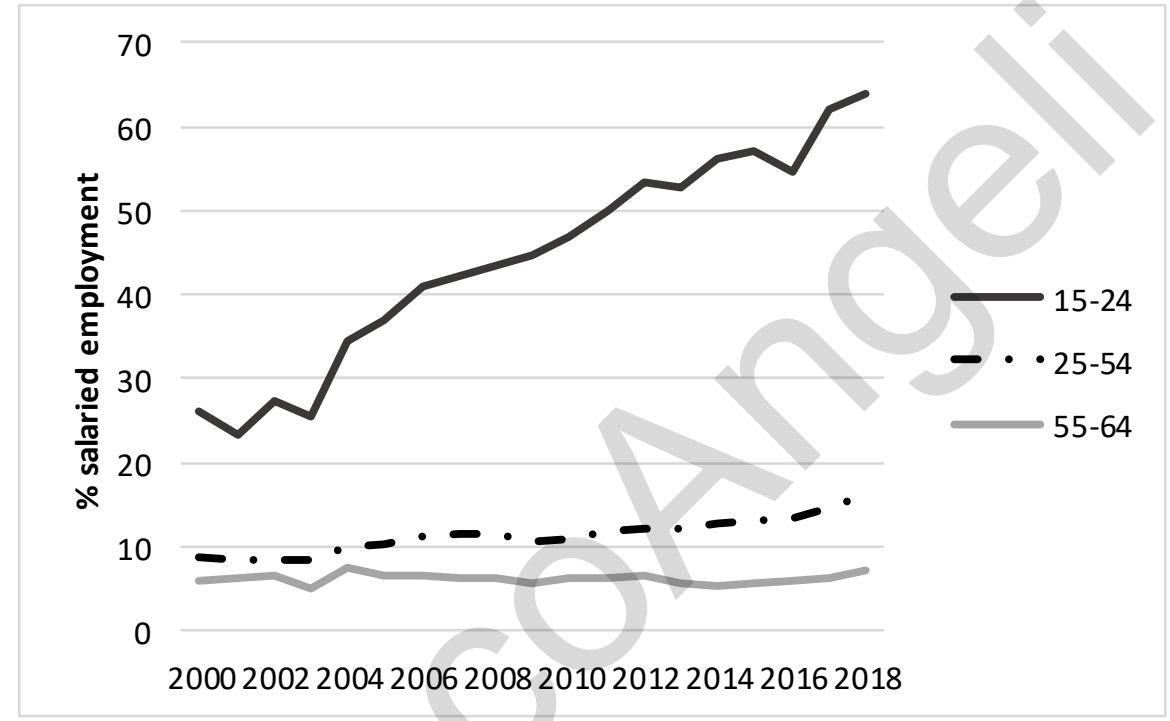

Source: Our elaboration on Eurostat database.

Moreover, temporary employment among young people rarely represents a choice on their part, but simply the only available option available, as shown in Figure 2.

As regards gender inequalities, no serious discussion has ever taken place, nor indeed any measures introduced, in relation the work-family balance. Saraceno and Keck (2010) classify Italy as a country with largely incomplete de-familisation policies, which end up burdening women with unpaid care work. As we know, the consequence of this is the low level of female employment. For instance, with regard to childcare policies concerning children under the age of three, the percentage of such children benefiting from childcare has remained stationary at just over $12 \%$. 
Fig. 2 - Involuntary temporary employment: young people

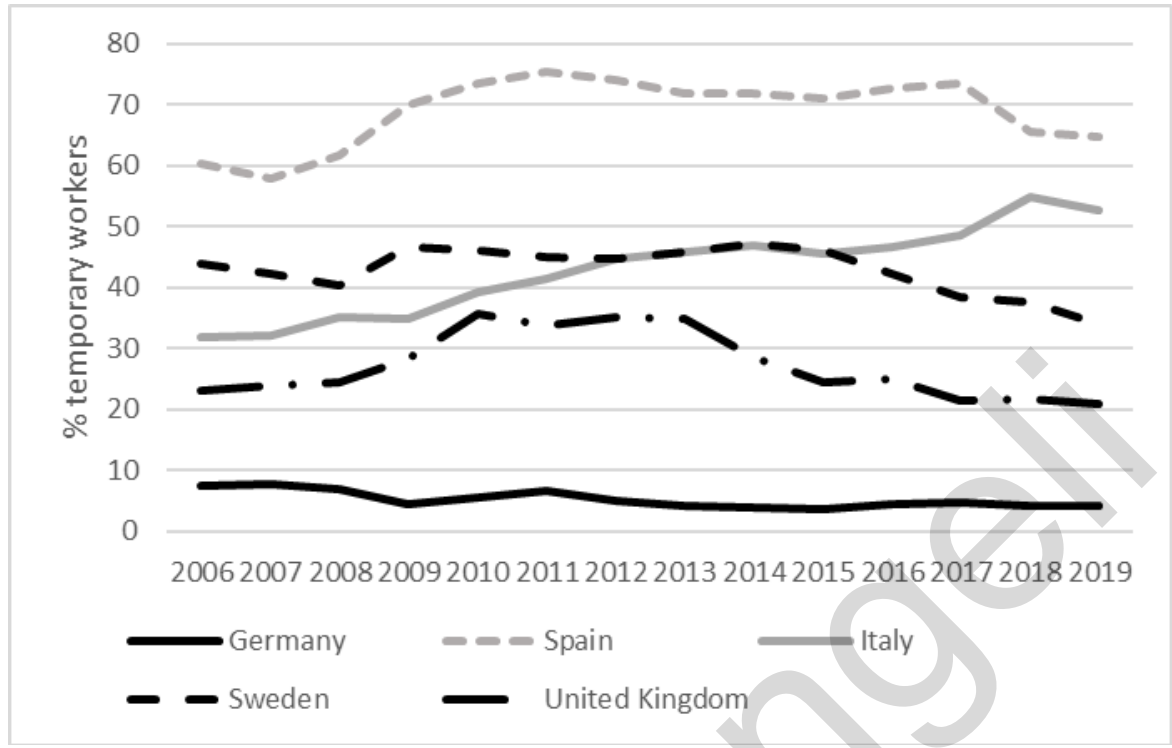

Source: Our elaboration on Eurostat database.

Furthermore, active labour market policies do not provide for job placement schemes (see next paragraph), and this shortcoming penalises women more than men, as a relatively small percentage of Italian women are actually in work.

Tab. 1 - Inactive women in selected European countries \%

\begin{tabular}{lrrrrrr}
\hline & 1995 & 2000 & 2005 & 2010 & 2015 & 2019 \\
\hline Denmark & 26.7 & 24.1 & 24.1 & 25.4 & 26.4 & 23.9 \\
Germany & 38.7 & 37.0 & 33.1 & 29.1 & 26.9 & 25.1 \\
Italy & 57.6 & 53.8 & 49.5 & 48.9 & 45.9 & 43.5 \\
UK & 34.0 & 32.2 & 31.2 & 30.7 & 28.3 & 26.2 \\
\hline
\end{tabular}

Source: Eurostat.

Even when women have jobs, their employment lowers with the presence of small children. In fact, women with young children often give up their jobs to look after them. The opposing trend is seen in men; the rate of employment of men increases in the presence of children. 
Tab. 2 - Rate of employment of men and women with children in Italy

\begin{tabular}{lrr}
\hline Number of children & Women & Men \\
\hline 0 & 47.52 & 61.29 \\
1 & 50.27 & 71.09 \\
2 & 53.42 & 83.61 \\
3 or more & 39.95 & 78.98 \\
\hline
\end{tabular}

Source: Eurostat.

Another factor penalising Italian women is a result of the 2009 economic crisis, and derives from the type of employment available when family incomes decline. What has emerged after the onset of the crisis is the "supplementary female worker effect" (Reyneri and Pintaldi, 2013), that is, women looking for work to make up for the fact that the breadwinner - a man - has lost his job. However, this kind of dynamic has mainly resulted in opportunities for part-time work. Given that in order to make up the shortfall caused by the man losing his job, a full-time job would be required, the rise in part-time working among women is largely of an involuntary nature in Italy (see Fig. 3).

Fig. 3 - Involuntary part-time: female employment

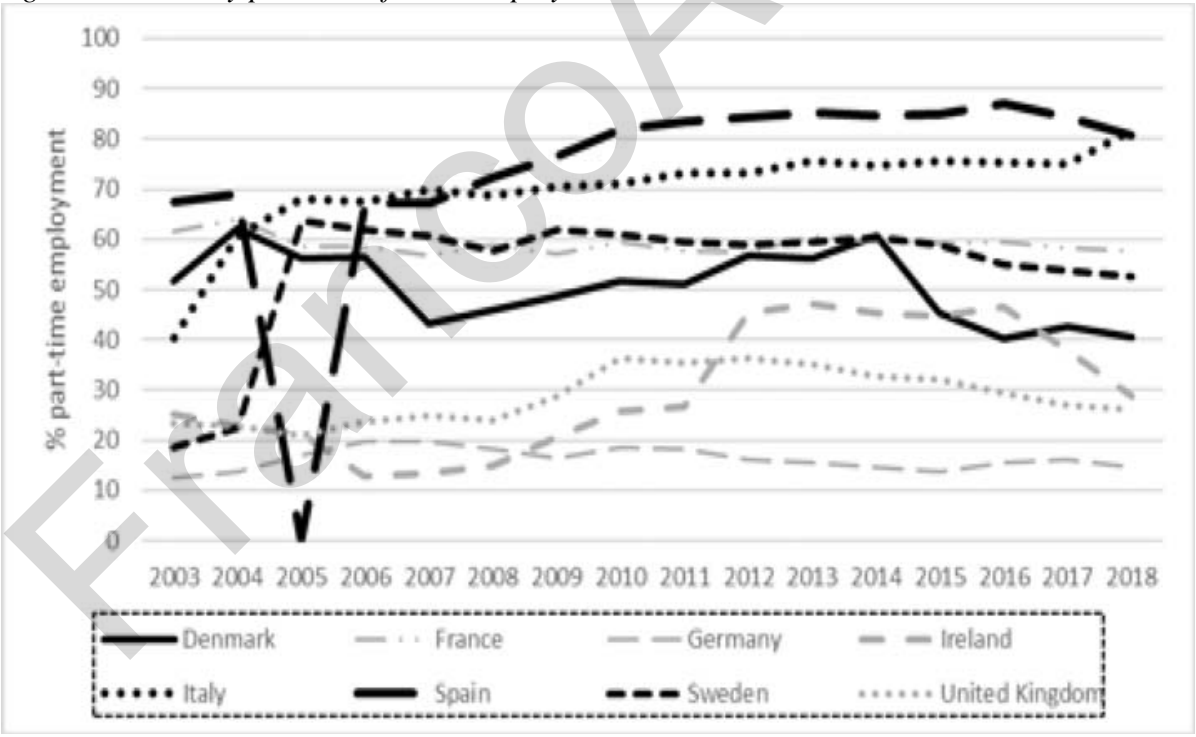

Source: Eurostat. 


\section{Between national insurance indemnity and unemployment benefit: the role of short-time work schemes and the failure to reform social safety net provisions}

An account of protection schemes implemented to counter unemployment would not be complete without taking into consideration the role played in Italy by ordinary and extraordinary redundancy fund ('Cassa Integrazione Guadagni Ordinaria e Straordinaria'), which has become a key feature of labour market policies designed to safeguard the earnings and jobs of those already in work. This is clearly illustrated by the way the 2009 economic crisis was handled. While the total employment rate fell from $62.7 \%$ in 2007 to $59.7 \%$ in 2013 , the unemployment rate doubled to $12.1 \%$ during that same period. The majority of the newly unemployed, however, were those on expired fixed-term contracts, whereas those workers on permanent contracts were sustained not only by insurance schemes, but also by short-time working plans, that is, by the aforementioned special redundancy fund.

Redundancy Fund, a common form of income support in Italy during times of crisis, is not based on a right but on a concession made by the State and the regions following the examination of the situation by the employers' associations and the trade unions.

The onset of the economic-financial crisis during a period in which Italy was governed by a centre-right coalition led by Silvio Berlusconi, and which resulted in a fall in GDP of 5.5\% in 2009, together with a fall in employment figures of $380,000(-1.6 \%)$, mainly men, was something that Italian labour market policies could not cope with. The principal measure taken was to strengthen the extraordinary temporary redundancy fund scheme ("emergency social shock absorbers"). Firms were allowed to extend and accumulate their employees' entitlement to the extraordinary and ordinary redundancy funds beyond the limits in place up until that moment. In fact, in order to cope with the sharp economic downturn and the loss of jobs, the 2008 Finance Act (Law no. 203) made it possible to supplement state aid with other exceptional social safety-net provisions, by making the criteria of eligibility for the temporary redundancy fund and the job mobility allowance more flexible than they had been up to that point; businesses and firms that had previously been excluded from the scheme, due to their size or sector, were now included, and provision was also made for benefits to be paid to temporary workers who had previously not been covered by the scheme. So, during the 2009-2010 period the main measures emerged to combat the crisis in Italy were centred on the redundancy fund: a protective scheme controlled by the Government. These required the cooperation of 
regional administrations, by including them in the implementation of emergency social safety-net provisions, following lengthy discussions about the resources needed to implement such a measure. The key role played by regional governments was further strengthened by the stipulation of specific agreements with the Central Government, which permitted regional administrations to combine their own funds and those assigned by the European Social Fund's 2007-2013 plan.

Consequently, a process of labour market policy regionalisation began, and this resulted in different regions managing the social safety-net schemes in different ways. This measure was originally intended to be of brief duration, but was in fact extended until the year 2012. Given the persistence of the economic crisis, the choice of the redundancy fund as the principal instrument of Italy's labour market policy also reflected the decision to utilise this measure as an industrial policy tool in order to sustain employment among the country's firms and to support aggregate demand. This decision was also justified by the broad consensus it generated. The trade unions' support for redundancy fund is understandable: on the one hand it protects workers in industry, who are traditionally the most highlyunionised ones; while on the other hand, the unions (together with the employers' associations) have to be consulted in regard to the use of this instrument, and they take part in the corresponding negotiations, and thus have a voice in regard to this measure that is of a discretionary nature. At the same time, firms are also in favour of the use of the temporary redundancy fund, given that its cost to them is lower than that of other such instruments. The national insurance contributions on lost earnings due to reduced hours, apart from a fixed contribution paid by the employees concerned, are in fact disbursed by the State. In this respect, Italy diverges from other European countries in terms of the use of short-time work schemes: this difference consists in the fact that Italian businesses do not pay welfare contributions when making use of the temporary redundancy fund. Finally, the generally favourable view expressed by employers' associations and trade unions (with the exception of the CGIL trade-union federation) was also the result of another decision taken by the Berlusconi government: the decision to reinforce the role of bilateral entities, composed of representatives from both unions and business associations, in the handling of various matters (training above all, but also unemployment benefits).

Despite the window of opportunity offered by the financial crisis to reform Italy's income support system in the event of unemployment, the measures adopted during the two-year period 2009-2011 further raised the stakes in regard to any change in the status quo. The Berlusconi government, as a result of the temporary redundancy fund and other extraordinary 
safety-net measures, managed to curb the rise in unemployment compared to what would have happened if other measures had been adopted (refraining from offering firms incentives not to dismiss employees, and radically reforming unemployment benefit), and used this result as political capital regardless of its efficacy. Employers were able to maintain their labour forces and their productive potential free of charge; the trade unions, for their part, were further empowered as policy brokers, and also as distributors of benefits thanks to the powers assigned to the bilateral entities; regional governments, on the other hand, acquired considerable resources thanks to the emergency safety-net measures, and their role was publicly legitimised and extended also in relation to passive labour market policies, in addition to their existing role in delivering active policies. It appeared extremely difficult to change this balance of interconnected vested interests. This was the challenge facing the government of technical experts led by Mario Monti that was to replace Berlusconi's government in late 2011 due to the latter's incapacity to take decisive measures to increase foreign investors' faith in Italy following the exogenous shock generated by the sovereign debt crisis.

Before detailing the measures introduced, we should point out that various steps were taken in implementing the reform. In early 2012 negotiations began between the Italian government and the social partners, during which the government called for the introduction of changes to labour market policy, arguing that the maintenance of the status quo was out of the question, and that it would take unilateral action if no agreement was reached. An agreement was reached in regard to the re-regulation of temporary employment and bogus self-employment, but the government was forced to drop its original plan to abolish the temporary redundancy fund due to opposition to this plan from the social partners, and in particular from the Confederation of Italian Industry (Confindustria). With regard to employment protection legislation, the Prime Minister proposed that Article 18 of the Workers' Statute be modified, and also that in the event that a court found in favour of a worker in legal proceedings brought for unfair dismissal, the only available remedy be monetary compensation, thus abolishing the previous option of the worker's reinstatement. The CGIL opposed this proposal and threatened strike action. The situation was eventually resolved through the mediation of the Democrat Party (PD), and a compromise agreement between government and the social partners was reached which provided for the reinstatement of any worker fired for purely economic reasons.

However, the dualisation of the labour force, which was split between those workers employed by small firms and those working for large firms 
(respectively, those firms with fewer than, and those with more than, 15 employees), continued to exist. Moreover, unlike what happens in Germany, in the event of dismissal there is provision for severance indemnity, and in order to obtain compensation for dismissal a worker needs to apply to the court and challenge his/her dismissal. The same applies to temporary workers, in that no compensation is envisaged for failure to renew a worker's employment contract (contrary to what happens in countries like Spain and France, for example).

As far as concerns redundancy fund, as previously mentioned, its proposed abolition was rejected by the social partners, and in particular by the Confederation of Italian Industry. The government thus proposed its use to be extended to companies that had not previously enjoyed the benefit of the measure, in order to lessen the need for extraordinary safety-net provisions. However, Italy's larger companies opposed this move, arguing that measures of the kind had already been negotiated and therefore the proposal was worthless. The reform of the temporary redundancy fund scheme was therefore never completed, while the bilateral entities' intervention was reinforced through the provision of new funds to companies with more than 15 employees. These resources provided benefits similar to those established by the ordinary and extraordinary temporary redundancy funds but, unlike the latter schemes, the social insurance contributions on lost earnings were to be paid by the parties concerned, thus reducing the burden on the public coffers. Furthermore, unlike in the case of the ordinary and extraordinary redundancy fund schemes, a limit was set on any reduction in working hours. Finally, while in certain sectors of the economy, employers and trade unions were incapable of establishing jointly-managed funds, firms with more than 15 employees could avail themselves of funds managed by central government. Firms with fewer than 15 employees may (but are not obliged to) have recourse to the bilateral sectoral funds. What clearly emerges, therefore, is that such measures failed to reduce dualisation in Italian labour market policies.

\section{An unstable and weak system of active labour market policies}

With regard to active policies, the only measure that has been recently introduced refers to employment services. It establishes, jointly with Regional Governments, the minimum levels that employment services are required to guarantee, and the award of premiums for meeting such levels.

In 2015, the new centre-left government, led by Matteo Renzi, promulgated the Jobs Act. This legislative measure pursued a de-regulation of 
statutory employment protection: only newly-hired employees were to be the recipients of the new "employment contracts providing increasing job protection" - a form of permanent employment contract. The "increasing" nature of the safeguards offered consisted in lower and upper limits on compensation, while the system of compensation in the case of firms with fewer than 15 employees differed from that applied to larger firms. Moreover, Article 18 of the Workers' Statute was amended by establishing that in the event of "unfair" dismissal - whether for economic reasons, that is, due to the firm's financial situation, or for disciplinary reasons based on the worker's conduct - there would be no provision for the worker's reinstatement, but simply for monetary compensation. The right to reinstatement only remained applicable to certain specific cases of dismissal on disciplinary or discriminatory grounds.

The Jobs Act also addressed the question of social safety-nets, and replaced the existing unemployment benefit scheme, called social insurance provision for employment (ASPI) with the "The New Social Insurance Provision for Employment (NASPI)" which differs from its predecessor in a number of ways. From the point of view of the criteria for eligibility, 13 weeks of social security contributions in the 4 years prior to the period of unemployment now entitles a person to the corresponding benefit. Furthermore, a person must have worked for at least thirty days in the 12 months prior to the start of the period of unemployment to be eligible for the benefit, and the calculation base is the average monthly earnings over the previous 4 years. The benefit amount starts off at $75 \%$ of average monthly earnings, and this amount is reduced by $3 \%$ per month as of the first day of the fourth month of receipt of the benefit. The NASPI is paid monthly for a number of weeks equal to half the number of weeks for which social contributions were paid in the four years before the start of unemployment, and can be paid for a maximum of 78 weeks. Payment of the benefit is not only dependent on the recipient's state of unemployment, but also on his/her regular participation in the job re-start projects and professional requalification activities proposed by the employment services: failure to participate will result in the person in question incurring penalties. The NASPI does not cover permanent employees of the Italian civil service, whose likelihood of being made redundant is very slim, or agricultural labourers on permanent or temporary contracts who continue to be covered by agricultural unemployment provisions.

It should not be forgotten that the NASPI is a form of insurance benefit, and as such is characterised by the close correlation between social contributions paid and benefits received, and thus limits the entity of income support, in particular in the case of young people who are more likely than 
others to be doing temporary jobs and to work in a discontinuous manner. Given that this benefit is paid for half the number of weeks for which social contributions were paid in the four years before unemployment, it is only paid for short periods in the case of people who have only worked for a limited time or in a discontinuous manner. Finally, workers made redundant must have worked for at least 30 days over the course of the year prior to their redundancy. The aim of this is to prevent those who were employed for a short period in previous years (2-4 years) from being eligible, and to promote the permanence of regular work in the market.

This same period also saw the creation of the National Agency for Active Labour Market Policies, the purpose of which is to bolster and reorganise active policies. The failure of the referendum held to confirm the proposed reforms of the Italian Constitution, held in 2016, and the fall of the Renzi government, interrupted this reorganizational process.

\section{The politics of antipoverty measures in Italy}

In more recent years, Italy has been one of the European countries where poverty and social exclusion have spread the most, as a consequence of the deterioration of the labour market and the limitations of welfare provisions (Pavolini et al., 2015; Saraceno, Benassi and Morlicchio, 2020). The overall picture of in-work poverty in Italy reveals a combination of low-paid jobs, employment instability, insufficient labour demand, especially in the Southern regions and low work intensity (temporary and parttime work), in particular for women, for households with children and for immigrants (Barbieri et al., 2018; Saraceno, Benassi and Morlicchio, 2020). These characteristics reflect a strong geographic concentration of poverty and a high incidence of in-work poverty among families with children and among migrants, the latter group being the newest social group most hard hit by poverty and social exclusion.

In a context traditionally marked by the considerable segmentation of the labour market, with significant differences existing between core and peripheral workers, together with social policies' limited capacity to reduce the poverty rate (compared to the other major European countries: see fig. 4), the increase in social inequality has had significant effects on the welfare state. The weakness of those social policies designed to combat poverty reflect a long standing persistent passive imbalance in the Italian welfare system, due to the high spending on pensions and the low level of that one devoted to social assistance. 
Fig. 4 - Social expenditure on pensions and early retirement schemes (\% of GDP) and the impact of social transfers on poverty reduction (among those aged 18 or over), in 2017

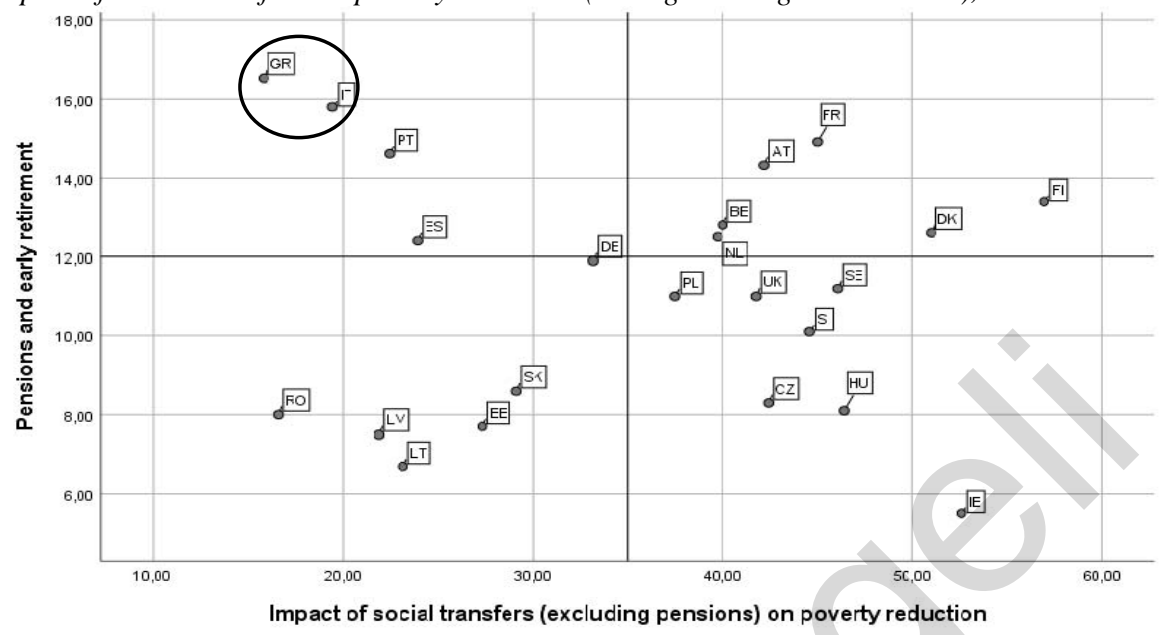

Source: our elaboration on Eurostat database.

In such a context, budget constraints contributed towards the reduction in welfare payments during the period from 2008 to 2017. In 2011, Mario Monti's "technical government" reduced the national social welfare policy fund to almost zero; this fund is used to finance the assistance provided by the country's local authorities. The cuts in welfare spending hit regional governments and local authorities in particular, which found themselves having to do more with less funding (Bordogna and Neri, 2014; Pavolini et al., 2015). At the same time, the economic crisis and the prolonged stagnation of Italy's economy, impacted the broadening of the category of lowpaid employment, in the absence of an appropriate system of anti-poverty support. Together with the entire Mediterranean area, Italy is characterised by an accumulation of diverse fragilities, in terms of both the supply of, and the demand for, welfare provisions (Pavolini et al., 2015). These fragilities include the severity of the economic downturn, low employment levels, the persistence of poorly-paid work, substantial inequalities, and the considerable incidence of in-work poverty (see Fig. 5). 
Fig. 5 - Inequalities (Gini index) and in-work poverty, in 2017

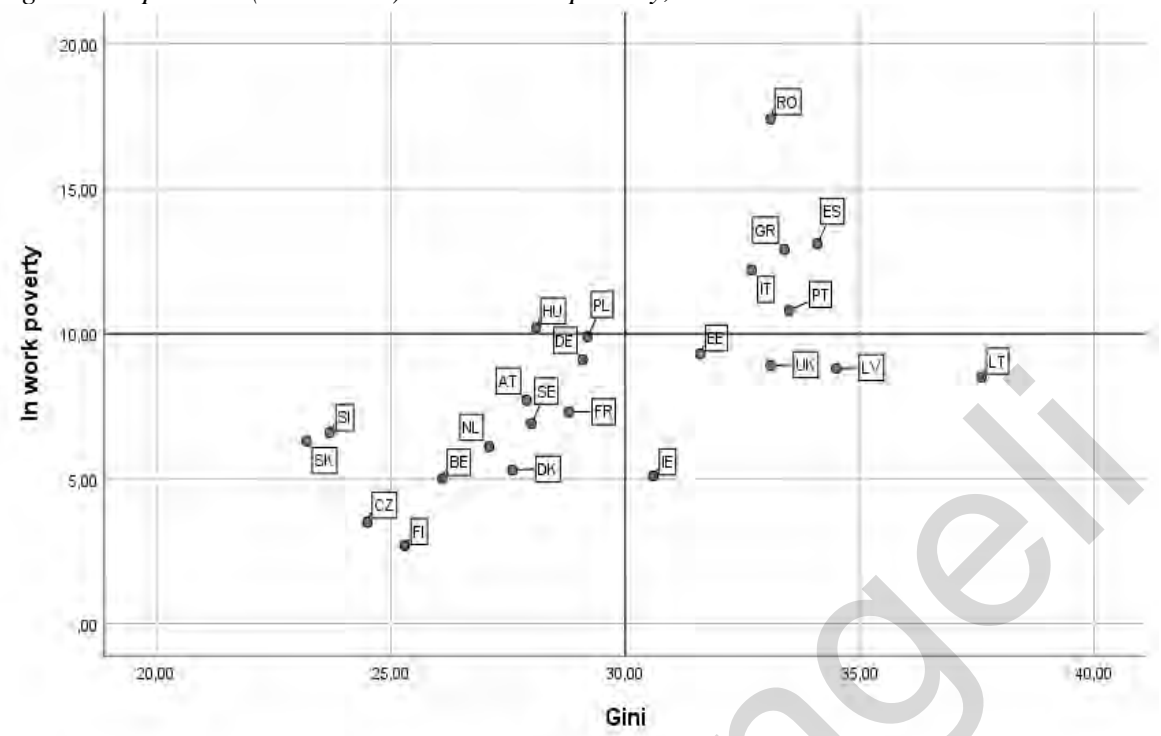

Source: our elaboration on Eurostat database.

Against this background, poverty and social exclusion became one of the most relevant topics of political debate following the outbreak of the economic crisis. Indeed, prior to the 2008 crisis, this kind of reform was only of modest interest within socio-political debate. It was only when the levels of poverty and social exclusion rose dramatically, that renewed pressure emerged for the introduction of a specific reform which began to influence the political agenda. On the one hand, a new heterogeneous network - the "Anti-Poverty Alliance" (Alleanza contro la povertà) emerged, prompting a transversal debate among civil society organisations, trade unions, institutions and policy makers. On the other hand, a new antiestablishment political actor, the Five Star Movement, entered the political arena, and this new movement demanded a radical reform aimed at introducing a universal minimum income scheme (the "Citizenship Income", Reddito di Cittadinanza, RdC). As several authors have pointed out (such as Ronchi and Terlizzi, 2018), the Five Star Movement was the political force that pushed hardest for the introduction of an antipoverty policy, using the Reddito di Cittadinanza as its own flagship proposal against the long-established political parties.

In an unprecedented effort, between 2016 and 2018 Italy completely revised its policy to combat poverty. In just two years, two different reforms completely reshaped the landscape of Italian antipoverty policies. The es- 
tablishment of the Inclusion Income by the Gentiloni government in 2016 marked a first important change in Italy's anti-poverty measures. One strongpoint of the Inclusion Income was undoubtedly its attempt to go beyond the lengthy series of experimental and indiscriminate measures that had characterised the previous years. The financial commitment, while of a substantial nature compared to the past ( 2 billion euro compared to 750 million spent on previous provisions), nevertheless remains below requirements in view of the significant increase in the risk of poverty. From a comparative perspective, the Inclusion Income remains a rather ungenerous measure, with the maximum amounts payable ranging from 168 euro for an individual, to 485 euro for large families, and is not sufficient to cover all of those living in absolute poverty in Italy. Nevertheless, the increase in spending it implied was significantly more than that of previous reforms.

In 2018, after the general election, the new anti-establishment yellowgreen coalition composed of the Five Star Movement and the Northern League (Lega Nord), reversed the previous scheme (Inclusion Income) and introduced a new one, the so-called Citizenship Income scheme (Reddito di Cittadinanza, $R d C$ ). The new governing coalition declared that the reform would constitute the means by which to eradicate poverty in Italy and help people return to work. With the introduction of the $\mathrm{RdC}$, together with the Citizenship Pension (a devoted antipoverty measure for over 67), spending on measures designed to combat poverty (5.9 billion euro in 2019, 7.1 billion in 2020, and 7.2 billion as from 2022) reached levels comparable to those of other European countries. The number of beneficiaries increased in an unprecedented manner, rising from 1.8 million to around 4 million, which is near to the number of individuals living in absolute poverty in 2017 (Gallo and Sacchi, 2019). The new welfare benefit consists of two components: the first component - "income" - is calculated on the basis of a family's income which must be below 6,000 euro (or 7,560 euro in the case of the Citizenship Income scheme) multiplied by a corresponding equivalence scale that increases the amounts. The second component of Citizenship Income consists in the reimbursement of rents paid (up to a maximum of 3,360 euro a year) or mortgage payments made (up to 1,800 euro a year). The overall entity of this benefit cannot exceed 9,360 euro per year (780 euro a month) multiplied by the equivalence scale, less the amount of a family's actual income (Inps 2020).

The introduction of the $\mathrm{RdC}$ was the result of a compromise solution formulated by the yellow-green coalition government, and was accompanied by a reform of the social security system that brought forward the retirement age for some people (the "quota 100" system where "100" stands for the combination of a minimum age of 62 years and 38 years of work- 
ing). This new measure, introduced in experimental form for the three-year period 2018-2021, was designed to relax somewhat the requirements for retiring and obtaining a state pension for those aged 62 or over with at least 38 years of insurance contributions (stamps). This measure is in addition to old-age pensions and early retirement schemes, and was conceived in order to support certain categories of workers in the manufacturing sector in Northern Italy (the League's traditional stronghold). Not only welfare spending (which increases as a consequence), but also policy design, were at stake in this mutual acceptance of the Five Star Movement's Citizenship Income scheme and the League's "Quota 100" system. Acceptance of a welfare provision of the size of the RdC (disliked by the League's voters) was in fact conditional upon the strengthening of an extremely "workfarist" approach to active labour market policies, with immigrants in practice excluded from the programme, because of extremely strict conditions regarding residency (10 yers). The underlying idea was to avert any form of dependency on assistance, by tightening controls and penalties, but also to use the minimum wage as an active labour market tool.

Compared to the previous REI, the changes made were substantial. As for conditionality, the new minimum income scheme institutionalizes a double track approach that is more conditioned and work-first for those who are required to sign a "Work pact" with the public employment services. In this case, the beneficiaries are required to accept at least one of three "suitable" job offers they receive in the first 18 months, and be prepared to dedicate up to 16 hours a week to "socially useful activities" as identified by the respective municipalities. The second track is designed for the most vulnerable groups affected by the risk of severe poverty and unable to work. In this case they have to sign a different "Social pact" with local social services, with no conditionality attached.

In terms of poverty reduction, the $\mathrm{RdC}$ has greatly strengthened social policies designed to combat poverty and social exclusion. Compared to the Inclusion Income, it undoubtedly marks a step forward in the fight against absolute poverty. The latest data released by the Italian National Statistics Institute (Istat, 2020) indicate that since its introduction, the $\mathrm{RdC}$ reduced the number of families living in absolute poverty by 148,000 in 2019. More recent data (Inps, 2020) highlight how, thanks to the RdC, the intensity of poverty has decreased, with positive effects on the fight against inequality since its introduction the Gini index has fallen from $33.9 \%$ to $33.2 \%$.

In this regard, while the impact of the $\mathrm{RdC}$ in terms of poverty reduction is unquestionable, many authors have criticised the introduction of an equivalence scale which favours single beneficiaries, while penalising large families. In fact, while unprecedented funds have been allocated to single- 
member households (up to 780 euro per month), large families have been penalised. Other concerns regard the poverty trap risk, especially in Italy's southern regions where the level of the benefit for a single beneficiary is close to the wage of many workers (Jessoula, Natili, and Raitano, 2019).

Nevertheless, most of the criticism aimed at the scheme has concerned its implementation. The populist narrative that characterised the introduction of the $\mathrm{RdC}$ in 2018, is based on the idea that poverty and work represent alternative conditions in the absence of any kind of in-work incentive or connection between benefits and a regular job. Despite the need to combine a variety of instruments such as employment services and in-work incentives, the new scheme neglected these issues. This is especially true for the working poor (i.e. those workers living in a household that has a disposable income of less than $60 \%$ of the national median). At present, the rules penalise such beneficiaries, since the benefit cannot be combined with work. Should a beneficiary find a regular job, the monetary transfer will be lowered. While in the vast majority of European countries in-work incentives are part of the minimum income policies, the RdC completely obscures this issue, with the unexpected effect of fuelling the combination of the benefit and irregular working.

A second criticism regards active labour market services and their integration with social assistance at local level. In a situation where social services are traditionally underdeveloped, while employment services play only a modest role as job brokers, active labour market policies have remained almost unchanged. In this regard, while the Inclusion Income aimed at strengthening social inclusion for the poorest, the new RdC has shifted the emphasis towards forcing people to work, including the working poor, without however the incentive of combining benefits and work, or a comprehensive system of social and active labour market services.

The need for a closer connection between active and passive measures would have required a massive strengthening of human resources devoted to facilitating labour inclusion. In contrast, many of the changes made have regarded the role of the so-called "navigator", that is, a specialized figure in charge of providing support and access to work for RdC beneficiaries within the local employment services.

In September 2019 the yellow-green coalition (after just one year of government) was replaced by a new governing coalition comprising the Five Star Movement and the Democratic Party. As a result of the Covid-19 pandemic, the new coalition promptly introduced substantial economic aid to numerous categories, extending benefits to workers excluded from the unemployment protection system. Other important measures comprised the suspension (until July 2020) of conditionalities, and the introduction of the 
Emergency Income (REM) scheme intended for those who do not benefit from other social safety nets. The Emergency Income is an unconditional individual benefit of 400 euros, which can amount to 840 euros per household, and is payable for a period of two months. The government's strategy at this moment in time is characterised by an attempt to broaden the scope of compensatory measures, without however completely reworking the $\mathrm{RdC}$, which has remained unchanged from how it was initially conceived under the previous yellow-green coalition. The result has been a deadlock, which has clarified the nature of the $\mathrm{RdC}$ project and brought to light those areas where it does not appear to be working. This is particularly true in terms of active labour market policies, the only such measure having been the suspension of conditionalities due to the negative impact of the pandemic.

\section{Conclusions}

This article has focused on the paths taken by the process of dualisation in Italy, with specific regard to two policy areas, namely labour market policies and antipoverty policies. Following the most recent political economy literature, we have understood dualisation as the effect not only of external pressures but of changes that have been inspired by unanticipated effects flowing from existing institutions (endogenous change), which have influenced the gap between insiders and outsiders. Within this framework, we have highlighted the trajectories followed by dualisation over the last twenty years, and in particular we have focused on the nature of the old and new outsiders, and of the coalitions of actors who have sustained the reconfiguration of the policies examined here. With regard to labour market policies, despite the presence of windows of opportunity resulting from contingent crises of various lengths, the promised rebalancing of the provisions concerning young people, women and the long-tern unemployed - the Italian outsiders' - has never materialised. The system of interwoven, historicallyrooted vested interests favouring the maintenance of the status quo, has never been overcome. In this situation, active labour market policies have remained of marginal importance, and there do not appear to be any coalitions of interests interested in strengthening such policies in sight ${ }^{1}$.

The institution of the $\mathrm{RdC}$ between 2017 and 2018 was the result of a

1. Despite the Prime Minister, Giuseppe Conte, having declared that 2021 will be the year of active policies. 
compromise formulated by the Northern League-Five Star Movement coalition government, and was accompanied by a reform of the social security system which brought forward the retirement age for some people (the "quota 100" system). This measure was introduced in addition to old-age pensions and early retirement schemes, and was conceived in order to help certain categories of workers in private industry in Northern Italy (the League's traditional stronghold). In this mutual trade-off between the Five Star Movement's Citizenship Income and the League's "Quota 100" system, the acceptance of a minimum income provision of this proportion was in fact conditional upon the activation of the recipients of the $\mathrm{RdC}$, but without active labour market policies being strengthened at all. In delegating responsibility for the activation of those receiving $\mathrm{RdC}$ to the public job centres, all that was done was to include so-called "navigators" among the ranks of the operators concerned (ironically, said navigators were temporary workers themselves), who were tasked with bringing together labour supply and demand. This measure, rather than reinforcing active policies in an organic manner, has merely harshened controls and penalties. Thus in practice, both the RdC and the Emergency Income scheme (introduced by the coalition government formed by the Democratic Party and the Five Star Movement to help deal with the pandemic) have strengthened the income support system, and have had positive effects on the efforts to combat absolute poverty.

The processes of dualisation observed in the Italian case are not consistent with the conventional divides observed in the current comparative political economy studies. Rather than a stable equilibrium between insiders and outsiders, dualisation in Italy has been mitigated by a more inclusive social safety net for atypical workers and more recently also for the poor. Over the course of the years, the income support system has been gradually extended to offer protection to people who had previously been excluded; in particular, young people without stable employment, and more recently the poor. The reforms have not concerned social safety net provisions as a whole. These have remained separate spheres in relation to which specific measures have been introduced, in the form of incremental, rather than systemic, reforms. In other words, the strategy pursued is based on a process of subsidising outsider precariousness. And both the trade unions and business associations have supported the exceptional extension of emergency social shock absorbers and the social safety-nets, to be funded by increasing public debt (especially in the last year as a result of the economic crisis caused by the pandemic) and general taxes. On the other hand, the institution of the RdC has bridged a clear gap in the Italian's welfare system, providing a basic income for the poor, without however being part 
of a more organic review that ties assistance and active labour market policies, with the latter totally neglected.

\section{References}

Barbieri P., Scherer S. (2005). Le conseguenze sociali della flessibilizzazione del mercato del lavoro in Italia. Stato e mercato, 25(2): 291-322. DOI: $10.1425 / 20484$

Barbieri P., Cutuli G., Scherer S. (2018). In-work poverty in un mercato del lavoro duale: individualizzazione riflessiva dei rischi sociali o stratificazione della diseguaglianza sociale?. Stato e Mercato, 114(3): 419-460. DOI: 10.1425/91627

Berger S., Piore M.J. (1980). Dualism and Discontinuity in Industrial Societies. Cambridge Mass: Cambridge University Press.

Berton F., Richiardi M. and Sacchi S. (2012). The political economy of work, security and flexibility: Italy in comparative perspective. Bristol: The Policy Press.

Bordogna L., Neri S. (2014). Austerity policies, social dialogue and public services in Italian local government. Transfer, 20(3): 357-371. DOI: $10.1177 / 1024258914535548$

Eichhorst W., Marx P. (2020). How stable is labour market dualism? Reforms of employment protection in nine European countries. European Journal of Industrial Relations, first published online: January 31. https://doi.org/10.1177/0959680119899199

Emmenegger P., Häusermann S., Palier B. and Seeleib-Kaiser M., ed. (2012). The age of dualization: The changing face of inequality in deindustrializing societies. Oxford: Oxford University Press.

Esping-Andersen G., Regini M., eds. (2000). Why deregulate labour markets?. Oxford: Oxford University Press.

Gallo G., Sacchi S. (2019). Beneficiari e spesa del reddito di cittadinanza: una stima della misura finale. Roma: Inapp Policy Brief. http://oa.inapp.org/xmlui/handle/123456789/364

Greif A., Laitin D. (2004). A Theory of Endogenous Institutional Change. American Political Science Review, 98(4): 633-652. DOI: 10.1017/S0003055404041395

Hall P., Thelen, K. (2009). Institutional Change in Varieties of Capitalism. SocioEconomic Review, 7(1): 7-34. DOI: 10.1093/ser/mwn020

Hassel A. (2014). The paradox of liberalization - Understanding dualism and the recovery of the German political economy. British Journal of Industrial Relations, 52(1): 57-81. https://doi.org/10.1111/j.1467-8543.2012.00913.x

INPS (2020). XIX Rapporto annuale, Roma.

ISTAT (2020). Nel 2019 in calo la povertà assoluta, 16 giugno.

Jessoula M., Natili M. and Raitano M. (2019). Italy: Implementing the new minimum income scheme. ESPN Flash Report 2019/35.

Kalleberg A.L. (2003). Flexible Firms and Labor Market Segmentation: Effects of Workplace Restructuring on Jobs and Workers. Work and Occupations, 30(2): 154-175. DOI: $10.1177 / 0730888403251683$ 
Palier B., Thelen K. (2010). Institutionalizing dualism: Complementarities and change in France and Germany. Politics \& Society, 38(1): 119-148. DOI: $10.1177 / 0032329209357888$

Pavolini E., León M., Guillén A.M. and Ascoli U. (2015). From Austerity to permanent strain? The EU and welfare state reform in Italy and Spain. Comparative European Politics, 13(1): 56-76. http://dx.doi.org/10.1057/cep.2014.41

Pontusson J. (2009). Once Again a Model: Nordic Social Democracy in a Globalized World. Futures of the Left. Durham: Duke University Press.

Reyneri E., Pintaldi F. (2013). Dieci domande su un mercato del lavoro in crisi. Bologna: il Mulino.

Rueda D. (2007). Social democracy inside out: Partisanship and labor market policy in advanced industrialized democracies. Oxford: Oxford University Press.

Rueda D. (2014). Dualization, crisis and the welfare state. Socio-Economic Review, 12(2): 381-407. https://doi.org/10.1093/ser/mwu015

Saraceno C., Keck W. (2010). Can we identify intergenerational policy regimes in Europe?. European Societies, 12(5): 675-696. https://doi.org/10.1080/14616696.2010.483006

Saraceno C., Benassi D., Morlicchio E. (2020). Poverty in Italy: Features and Drivers in a European Perspective. Bristol: Policy Press.

Thelen K. (2012). Varieties of capitalism: Trajectories of liberalization and the new politics of social solidarity. Annual Review of Political Science, 15(1): 137-159. https://doi.org/10.1146/annurev-polisci-070110-122959

Thelen K. (2014). Varieties of liberalization and the new politics of social solidarity. Cambridge: Cambridge University Press. 